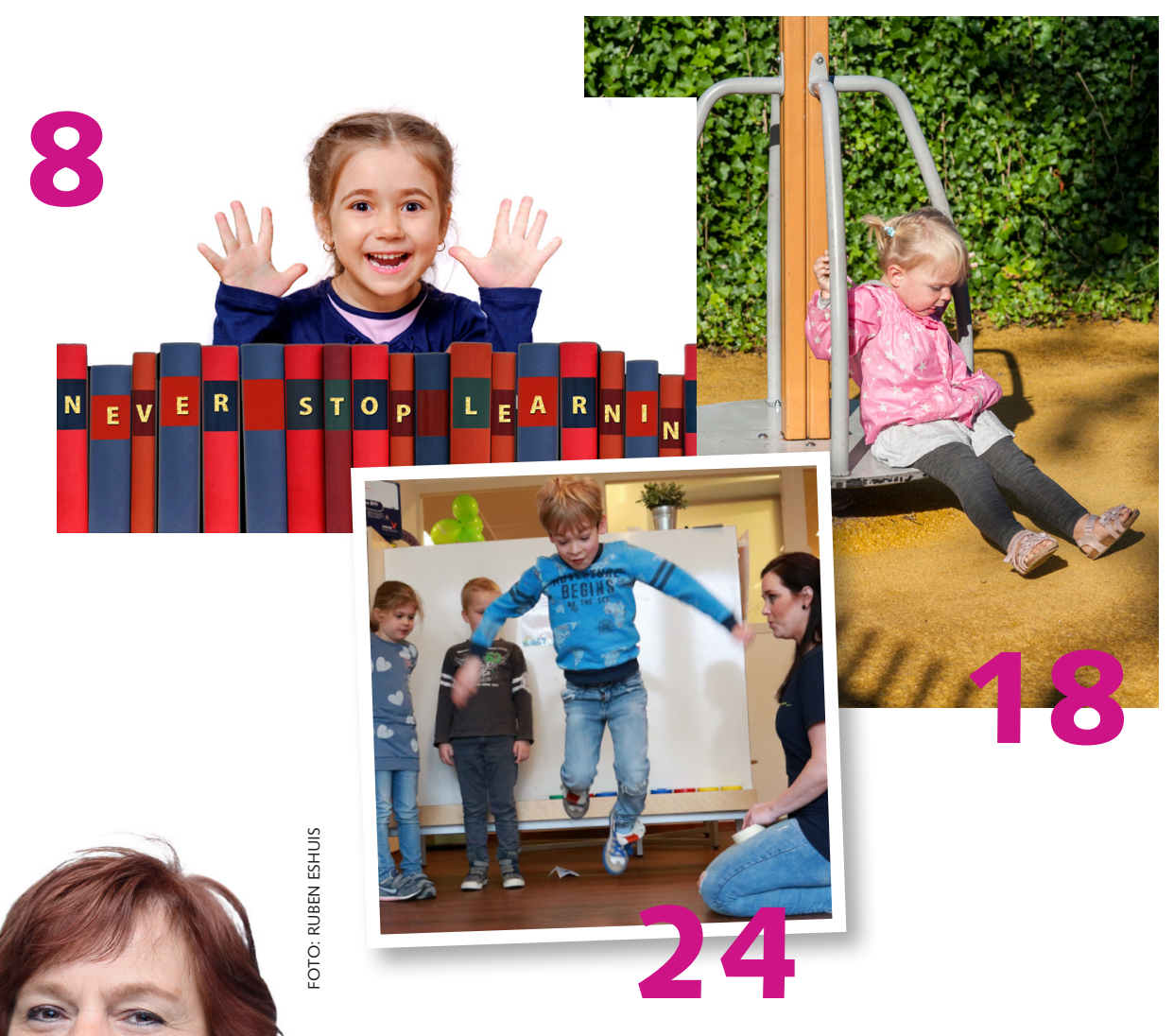

\section{Pas op, kijk uit!}

'Onze kinderopvangorganisatie onderscheidt zich door veiligheid. Ouders vinden dat namelijk erg prettig. We hebben wel een buitenruimte omdat die verplicht is, maar we gaan eigenlijk zo min mogelijk naar buiten met de kinderen. De risico's en valpartijen liggen daar op de loer. Kinderen gaan daar rennen en

kunnen dan tegen elkaar aanbotsen. Met fietsjes rondracen is ook erg gevaarlijk; ze kunnen zomaar tegen elkaar aanrijden en omvallen. Sowieso is het gevaarlijk buiten: er zitten insecten die kunnen steken, kinderen kunnen verbranden in de zon of kou vatten in de regen.

Klimtoestellen hebben we niet, zoals je zult begrijpen. Nee, wij blijven het liefst lekker binnen. Scheelt ook een hoop werk met al die jasjes en schoenen aantrekken. Maar binnen moet je ook erg oppassen trouwens. In de babygroep trekken we de baby's handschoentjes aan zodat ze niet een ander kindje kunnen krabben of in de ogen kunnen prikken. We voeren alle kinderen, ook in de bso, met een plastic lepeltje vanaf een bordje. Zo verslikken ze zich minder vaak en kunnen we ook precies bijhouden hoeveel ze eten. Dat vinden ouders ook prettig om te weten. En heb je ook niet het gedoe van zelf boterhammen smeren. Stel je voor wat ze met zo'n mes kunnen doen. Het liefst zetten we ze met kussens op de grond, ieder met hun eigen tablet zodat ze educatieve filmpjes kunnen kijken. Wat? Tabletnek? Overgewicht? Problemen met de motoriek? Shit, dan moeten we toch weer wat anders bedenken...' Hoe het óók kan? Lees verder op pagina 20.

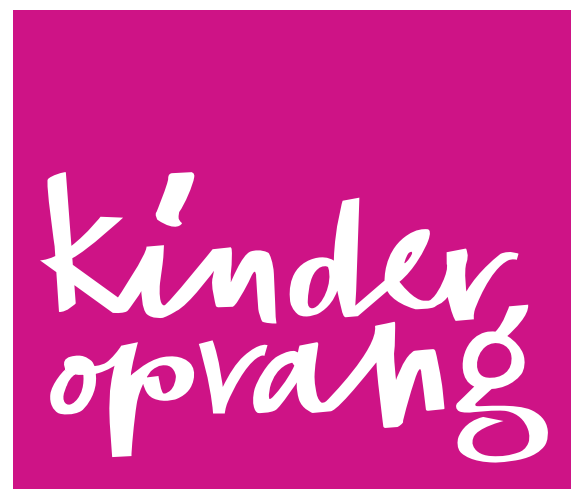

\section{INHOUD}

\section{Kort en krachtig}

8 VVE: de nieuwe eisen vanaf 1 juli

10 Rollenspel Beter begeleiden

13 Dit willen wij Ouders aan het woord

14 voel je sterk Werken aan zelfvertrouwen 16 Serie Moestuinieren Deel 4 - Oogsten 18 Kinderen die buiten de groep vallen

20 Avontuurlijk buitenspelen Goed of gevaarlijk?

\section{Puntje van Pont}

23 Column van orthopedagoog en pm'er Jaqueline Butti

24 Wiskids! Rekenen in de kinderopvang

27 Boekrecensie Grammatica van de fantasie

\section{Kinderyoga}

\section{Dialoog met de pedagoog}

30 Tips voor de zomer

\section{Mijn locatie}

32 Kids Actief Thema: waterweek

34 Kids Actief 8+ Escaperoom

\section{Kinderboeken}

36 PPINK Meer aandacht voor de bso 38 Gespot

39 Colofon 